\title{
Hydrogen Peroxide Increases during Endodormancy and Decreases during Budbreak in Grapevine (Vitis vinifera L.) Buds
}

\author{
Francisco Javier Pérez *D, Ximena Noriega and Sebastián Rubio \\ Laboratorio de Bioquimica Vegetal, Facultad de Ciencias, Universidad de Chile, Casilla 653, Las Palmeras, \\ Nuñoa 3425, Chile; XNoriegaguerrero@gmail.com (X.N.); rubio604@hotmail.com (S.R.) \\ * Correspondence: frperez@uchile.cl
}

check for updates

Citation: Pérez, F.J.; Noriega, X.; Rubio, S. Hydrogen Peroxide Increases during Endodormancy and Decreases during Budbreak in Grapevine (Vitis vinifera L.) Buds. Antioxidants 2021, 10, 873. https:// doi.org/10.3390/antiox10060873

Academic Editors: José Antonio

A. Hernández Cortés and

Gregorio Barba-Espín

Received: 26 April 2021

Accepted: 25 May 2021

Published: 29 May 2021

Publisher's Note: MDPI stays neutral with regard to jurisdictional claims in published maps and institutional affiliations.

Copyright: (c) 2021 by the authors. Licensee MDPI, Basel, Switzerland. This article is an open access article distributed under the terms and conditions of the Creative Commons Attribution (CC BY) license (https:/ / creativecommons.org/licenses/by/ $4.0 /)$.

\begin{abstract}
Changes in the level of hydrogen peroxide $\left(\mathrm{H}_{2} \mathrm{O}_{2}\right)$ is a good indicator to monitor fluctuations in cellular metabolism and in the stress responses. In this study, the changes in $\mathrm{H}_{2} \mathrm{O}_{2}$ content during bud endodormancy (ED) and budbreak were analysed in grapevine (Vitis vinifera L.). The results showed a gradual increase in the $\mathrm{H}_{2} \mathrm{O}_{2}$ content during the development of bud ED, which was mainly due to an increase in the activity of peroxidases (PODs). The maximum $\mathrm{H}_{2} \mathrm{O}_{2}$ content reached in the grapevine buds coincided with the maximum depth of bud ED. In contrast, during budbreak, the $\mathrm{H}_{2} \mathrm{O}_{2}$ content decreased. As the plant hormones cytokinin (CK) and auxin play an important role in budbreak and growth resumption in grapevine, the effect of exogenous applications of $\mathrm{H}_{2} \mathrm{O}_{2}$ on the expression of genes involved in CK and auxin metabolism was analysed. The results showed that $\mathrm{H}_{2} \mathrm{O}_{2}$ represses the expression of the CK biosynthesis genes VvIPT3a and VvLOG1 and induces the expression of the CK-inactivating gene $V v C K X 3$, thus reducing potentially the CK content in the grapevine bud. On the other hand, $\mathrm{H}_{2} \mathrm{O}_{2}$ induced the expression of the auxin biosynthesis genes $V v A M I 1$ and VvYUC3 and of the auxin transporter gene VvPIN3, thus increasing potentially the auxin content and auxin transport in grapevine buds. In general, the results suggest that $\mathrm{H}_{2} \mathrm{O}_{2}$ in grapevine buds is associated with the depth of ED and negatively regulates its budbreak.
\end{abstract}

Keywords: auxin; cytokinin; budbreak; dormancy; grapevine buds; hydrogen peroxide; peroxidases

\section{Introduction}

The buds of the grapevine (Vitis vinifera L.), similar to the buds of other deciduous fruit trees enter a state of winter recess or endodormancy (ED) to survive winter conditions. In the grapevine bud, ED is induced by the shortening of the photoperiod [1-3] and is regulated by endogenous factors that inhibit its growth and development [4]. The plant hormone abscisic acid (ABA) accumulates in the buds of grapevines throughout ED [5,6] and plays a key role in its maintenance and release [7-9]. On the other hand, hydrogen peroxide $\left(\mathrm{H}_{2} \mathrm{O}_{2}\right)$, which is continuously generated from various sources during normal metabolism and is a signalling molecule that mediates responses to biotic and abiotic stresses [10], also accumulates in the buds of grapevine during $\mathrm{ED}$ [11-13]. Further, $\mathrm{H}_{2} \mathrm{O}_{2}$ has been suggested to play a pivotal role in the control of ED and budbreak [14]. $\mathrm{H}_{2} \mathrm{O}_{2}$ can also be generated by specific enzymes such as the respiratory burst oxidase homologs $(\mathrm{RBOH})$, xanthine oxidase, amine oxidase and cell wall peroxidase [10]. Generally, the plant antioxidant system removes $\mathrm{H}_{2} \mathrm{O}_{2}$ efficiently, and thus the oxidative effects of many stimuli could be mediated via a reduction in the activities of antioxidant enzymes, rather than by increased $\mathrm{H}_{2} \mathrm{O}_{2}$ generation [10]. In grapevine buds, hypoxia, as well as mitochondrial respiration inhibitors, such as potassium cyanide (KCN) and sodium nitroprusside (SNP), increase $\mathrm{H}_{2} \mathrm{O}_{2}$ levels [15]. In Arabidopsis thaliana, hypoxia was found to activate Rop-GTPase signalling, which in turn activated $\mathrm{RBOH}$ [16]. In grapevines, seven $V v R B O H$ genes have been identified and characterised [17], and three of them are expressed in the buds [18]. Peroxidase class III (POD) represents a class of ubiquitous enzymes widely distributed 
in plants whose primary function is to oxidize molecules at the expense of $\mathrm{H}_{2} \mathrm{O}_{2}$. POD is therefore generally considered an $\mathrm{H}_{2} \mathrm{O}_{2}$ detoxifying enzyme; however, POD can also produce $\mathrm{H}_{2} \mathrm{O}_{2}$. In grapevines and peach, it has been reported that $\mathrm{POD}$ can generate $\mathrm{H}_{2} \mathrm{O}_{2}$ through the oxidation of $\mathrm{NADH}$, and this reaction is catalysed by p-coumaric acid [11,19]. Recently, a subfamily of $47 V v P O D$ genes was identified in the grapevine genome [20] and 30 subfamily members were expressed in the bud [18]. Oxidative stress and reactive oxygen species (ROS) have been suggested to play a central role in the release of buds from ED in grapevines [14]. Interestingly, most studies using chemical and physical dormancy breakdown stimuli such as hydrogen cyanamide (HC), sodium azide (AZ) and heat shock (HS) [11-13] show a transient increase in $\mathrm{H}_{2} \mathrm{O}_{2}$ levels within the grapevine bud, which has been interpreted as a positive signal for the release of buds from the ED [13,14].

In this study, the changes in $\mathrm{H}_{2} \mathrm{O}_{2}$ levels though ED and budbreak were analysed in grapevine buds. Additionally, the effects of exogenous applications of $\mathrm{H}_{2} \mathrm{O}_{2}$ on the expression of cytokinin $(\mathrm{CK})$ and auxin-related genes in grapevine buds were examined. From the results, we found that the $\mathrm{H}_{2} \mathrm{O}_{2}$ level is associated with the degree of ED and is a negative regulator of budbreak in grapevine buds.

\section{Materials and Methods}

\subsection{Plant Material}

Plant material was collected from 8-year-old (Vitis vinifera $\mathrm{L}$. cv. Thompson Seedless) vineyards growing at the experimental station of the Chilean National Institute of Agriculture Research (INIA) located in Santiago, Chile (33०34' S). The grapevine plants were watered by immersion and trained in an aerial training system. Six whole canes were randomly collected every 3 weeks starting at the beginning of January (early summer) and ending at the end of August (early spring). The collected canes were cut at both ends, leaving a central section of $10-12$ buds for experimental use.

\subsection{Dormancy Depth}

The budbreak response of single-bud cuttings under forced conditions is widely used to describe the depth of dormancy in grapevine [21,22]. Thirty cuttings were mounted on polypropylene sheets and placed in a container with water and transferred to a growth chamber set at $23 \pm 2{ }^{\circ} \mathrm{C}$ with $16 \mathrm{~h}$ (h) light. The budbreak was assessed every 5 days (d) during a period of $30 \mathrm{~d}$, the appearance of a green tip was the signal that indicated the beginning of the budbreak. This procedure was repeated for the different collection dates. The time required for each sample to reach budbreak, including right-censored observations of the buds that did not break during the treatment, was adjusted to the survival distribution function by the nonparametric Kaplan-Meier method [23]. The first sample of the year collected in early January before the onset of ED [24,25] was used as a reference of the behaviour of budbreak, when growth was not restricted within the buds (paradormant buds). A log-rank test was performed to compare the estimated survival distributions of the reference sample with samples collected at other dates. The greater the difference in the chi-square between the analysed sample and the reference sample, the greater the degree of ED [23].

\subsection{Chemical Treatments}

Single-node cuttings collected on June 11 were painted with $2.5 \%(w / v)$ hydrogen cyanamide (HC) (Dormex, SKW, Trotsberg, Germany), 2\% (w/v) 3-amino-1,2,4-triazole (Sigma, Burlington, VT, USA) or water, as a control. Cuttings were mounted on a polypropylene sheet and placed in a container with water and transferred to the growth chamber set at $23 \pm 2{ }^{\circ} \mathrm{C}$ under $14 \mathrm{~h} \mathrm{light} \mathrm{forced} \mathrm{conditions} \mathrm{(FC);} \mathrm{samples} \mathrm{were} \mathrm{removed} \mathrm{at} \mathrm{each} \mathrm{specific}$ point. Experiments inducing the breakage of ED were carried out with buds collected on July 18 and treated with $2.5 \%(w / v)$ HC, $2 \%(w / v) 3$-amino-1,2,4-triazole or water as a control. After treatments, cuttings were mounted as described above and settled in the growth chamber under FC and the breakage of buds was assessed every $2 \mathrm{~d}$. 


\section{4. $\mathrm{H}_{2} \mathrm{O}_{2}$ Measurements}

The $\mathrm{H}_{2} \mathrm{O}_{2}$ concentration was measured by chemiluminescence (CL) based on a cobaltcatalysed oxidation of luminol (5-amino-2,3-dihydro-1,4-phtalazinedione) [26]. Three different buds were analysed for each sampling date and values corresponded to the average of the three samples.

\subsection{Peroxidase and Catalase Activity}

Buds were ground in liquid nitrogen, and the resulting powder was extracted with a buffer containing $0.5 \mathrm{M}$ Tris-HCl, $5 \mathrm{mM}$ DTT, $1 \mathrm{mM} \mathrm{MgCl}_{2}, 10 \mu \mathrm{M}$ PMSF, $2 \%$ insoluble PVP and $12.5 \%$ glycerol ( $\mathrm{pH} 7.5$ ). Peroxidase (donor: hydrogen peroxide oxidoreductase EC1.11.1.7) activity was assayed according to [27] by measuring the $\mathrm{H}_{2} \mathrm{O}_{2}$-dependent oxidation of o-phenylendiamine (o-PDA) via spectrophotometry at 450 nanometers $(\mathrm{nm})$ in a mixture with $\mathrm{pH} 4.5$ containing $0.1 \mathrm{M}$ sodium citrate, $44 \mathrm{mM}$ o-PDA, $1 \mathrm{mM} \mathrm{H}_{2} \mathrm{O}_{2}$ and 5-10 $\mu \mathrm{L}$ of the extract. Catalase activity was determined following $\mathrm{O}_{2}$ evolution using a Clark-type oxygen electrode (Hansatech, UK) as according to the methodology of [12].

\subsection{RNA Purification, and cDNA Synthesis}

Total RNA was isolated and purified from dormant buds (0.5 g FW) of Thompson seedless. Total RNA was extracted and purified using the method of Chang et al. [28] modified according to Noriega et al. [29]. The DNA was removed from the sample with RNAse-free DNase I ( $1 \mathrm{U} / \mu \mathrm{g}$ ) (Thermo Scientific, Bedford, MA, USA) at $37^{\circ} \mathrm{C}$ for $30 \mathrm{~min}$. The first cDNA strand was synthesised from $1.0 \mu \mathrm{g}$ of purified RNA with $1 \mu \mathrm{L}$ of oligo (dT) 12-18 $\left(0.5 \mu \mathrm{g} \times \mu \mathrm{L}^{-1}\right)$ as a primer, $1 \mu \mathrm{L}$ of dNTP mixture $(10 \mathrm{mM})$ and Superscript ${ }^{\circ} \mathrm{II}$ RT (Invitrogen, CA, USA).

\subsection{Gene Expression Analysis}

The expression analysis of the genes was performed by quantitative real-time PCR (RT-qPCR) using an Eco Real-Time PCR system (Illumina, Inc. San Diego, CA, USA) and KAPA SYBR FAST (KK 4602) qPCR Master Mix $(2 \times)$. Sequences of grapevine genes were obtained from the grape genomic database (www.genoscope.fr, accessed on 24 May 2021). Primers for amplification were designed using PRIMER3 software [30]. The cDNA was amplified under the following conditions: denaturation at $94{ }^{\circ} \mathrm{C}$ for 2 min and 40 cycles of $94{ }^{\circ} \mathrm{C}$ for $30 \mathrm{~s}, 55^{\circ} \mathrm{C}$ for $30 \mathrm{~s}$ and $72{ }^{\circ} \mathrm{C}$ for $45 \mathrm{~s}$. Relative changes in gene expression levels were determined using the $2^{-\Delta \Delta C T}$ method [31]. Each reaction was performed with at least two biological replicates, each with three technical replicates. VvUBIQUITIN (GSVIVT01038617001) and VvACTIN (GSVIVT01026580001) were used as reference genes for normalisation.

\subsection{Data Analysis}

Survival analysis, or the time to event analysis, is a category of statistical methods designed specifically to handle a response variable that measures the elapsed time until a specific event occurs (here, budbreak), which may be censored [32]. Kaplan-Meier (KM) survival curves are the simplest way to estimate survival over time when data are censored [23]. The percentage or probability of absence of budbreak is calculated as a function of time after sampling according to the KM method. However, in this study, we used the complement of the probability of the absence of budbreak, which corresponds to the probability of budbreak [23]. A log-rank test was carried out to compare the estimated survival distribution of the reference sample against the other samples. A significant difference indicates differences in the budbreak distribution curves, and the larger the value of the chi-square $\left(x^{2}\right)$ is, the greater the difference between the reference and the other sample, thus the greater the ED depth of the sample. 


\section{Results}

\subsection{Depth of Endodormancy and $\mathrm{H}_{2} \mathrm{O}_{2}$ Content in Grapevine Buds}

The survival analysis of the budbreak of grapevine buds under forced conditions was carried out on the different collection dates using the nonparametric Kaplan-Meier method [23]. The comparison of the KM probabilistic function between the buds collected before (reference) and after the onset of the ED was performed using a log-rank test. The greater the chi-square between the reference and the samples, the greater the degree of ED [23]. Using this methodology, two phases were distinguished during ED in Thompson seedless grapevines grown in Santiago, Chile. The first phase began in mid-January and lasted until mid-April, and the second phase peaked in late May and ended in late August. During the second phase of the ED, a sustained increase in the $\mathrm{H}_{2} \mathrm{O}_{2}$ content was observed, whose maximum coincided with the maximum depth of the ED (Figure 1). This dormancy pattern is consistent with the transcriptome changes observed during bud development in grapevines [18].
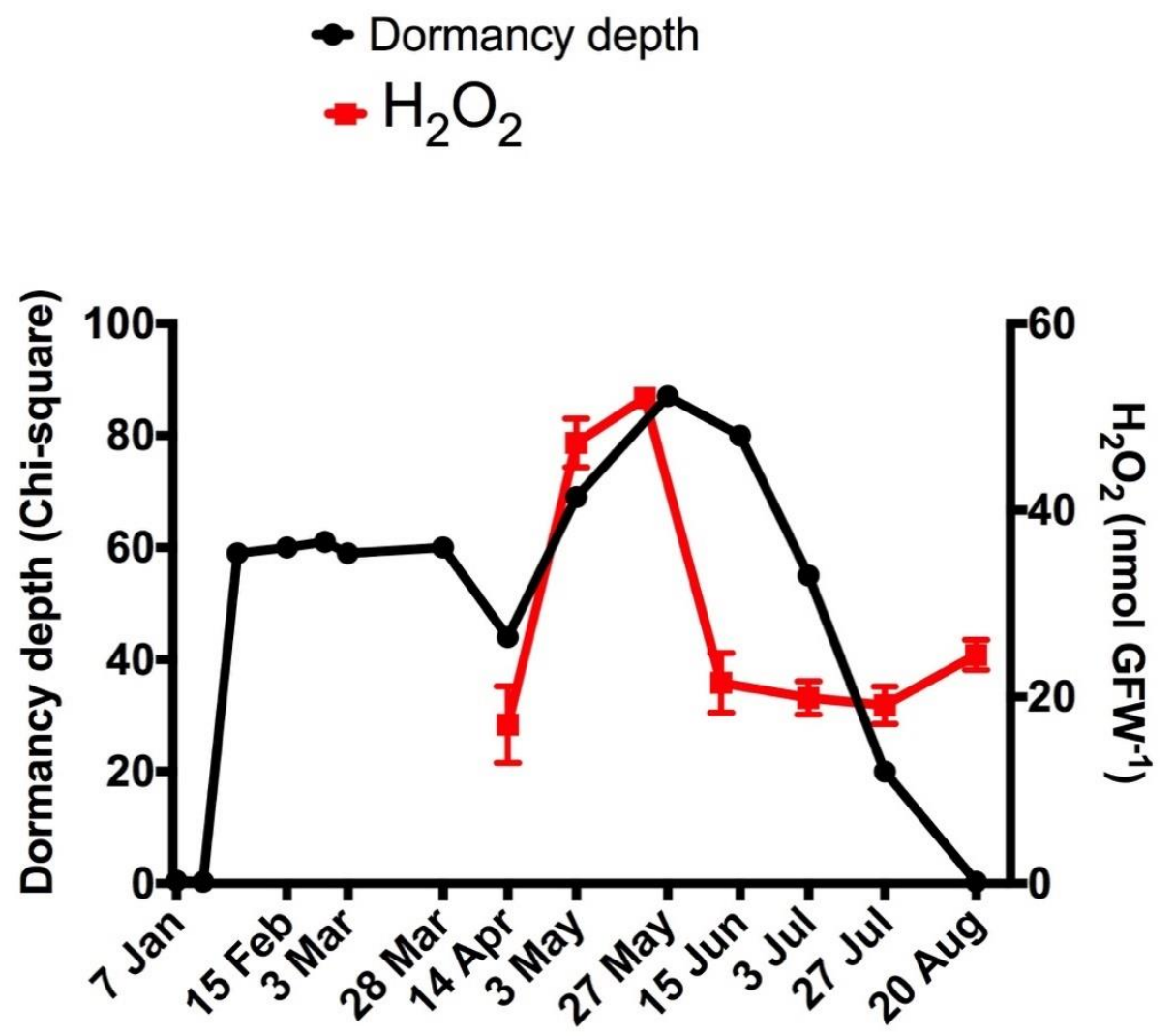

Figure 1. Relationship between the degree of endodormancy and $\mathrm{H}_{2} \mathrm{O}_{2}$ levels in Thompson seedless grapevine buds grown in Santiago, Chile. The degree of dormancy was determined by means of a log-rank test between the probabilistic function $\mathrm{KM}$ of the buds collected before (reference) and after the onset of the ED [26]. $\mathrm{H}_{2} \mathrm{O}_{2}$ was determined by a chemiluminescence method [29].

3.2. Increases in Peroxidase Activity and $\mathrm{H}_{2} \mathrm{O}_{2}$ Content Coincided through Endodormancy in the Grapevine Buds

In grapevine, it has been reported that peroxidases (PODs) can generate $\mathrm{H}_{2} \mathrm{O}_{2}$ by oxidation of $\mathrm{NADH}$, and this reaction is catalysed by p-coumaric acid [11]. Here, we analysed the POD activity throughout the ED period in Thompson seedless grapevine buds, and this activity was compared with the evolution of the $\mathrm{H}_{2} \mathrm{O}_{2}$ content in the buds (Figure 2a). The results showed that the maximum POD activity coincided with the maximum $\mathrm{H}_{2} \mathrm{O}_{2}$ content, suggesting that the POD activity may be at least partially responsible for the increases in the $\mathrm{H}_{2} \mathrm{O}_{2}$ content in grapevine buds. The increase in 
POD activity is probably due to an increase in protein abundance, since the expression of $V v P O D s$ genes increased (see Section 3.3).

a

$$
\sim \mathrm{H}_{2} \mathrm{O}_{2}
$$

- VvPOD activity

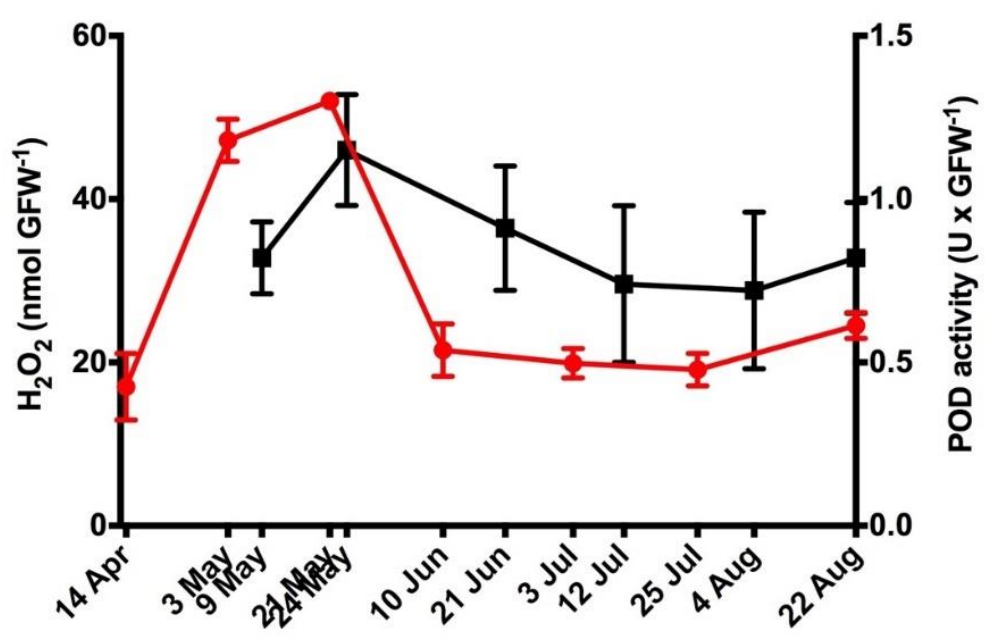

b VvPODs

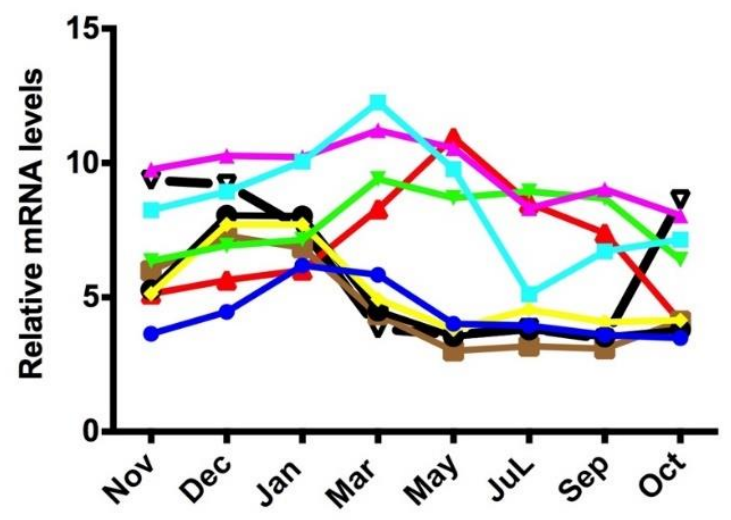

$\rightarrow V v P O D 30$

$=V V P O D 46$

$-V_{V P O D 27}$

$-V_{V} P O D 32$

VVPOD17

VVPOD18

- $V V P O D 2$

$\pm V V P O D 38$

$-V_{V} P O D 25$

Figure 2. Expression of peroxidase genes ( $V v P O D s)$, peroxidase activity and $\mathrm{H}_{2} \mathrm{O}_{2}$ levels during grape bud endodormancy. (a) Relationship between $\mathrm{H}_{2} \mathrm{O}_{2}$ levels and peroxidase activity (VvPOD) during endodormancy in Thompson seedless grapevine buds grown in Santiago, Chile. (b) Changes in the expression of peroxidase genes $(V v P O D)$ throughout bud growth in Tempranillo grapevines grown in Alcalá de Henares, Madrid [21] and adapted to the Southern Hemisphere conditions.

\subsection{Expression Profile of VvPOD Genes throughout the Endodormancy in Grapevine Buds}

A total of $47 V v P O D$ genes have been identified in the $V$. vinifera genome [20], and a phylogenetic tree revealed that $V v P O D s$ showed a relatively close genetic relationship with similar genes from Arabidopsis [20]. Of this large number of $V v P O D s, 30$ are expressed in the bud [18], and nine change their expression level during the development of ED. The transcript levels of $V v P O D s$ taken from microarray data on the development of Tempranillo grape buds grown in the Northern Hemisphere [18] were plotted throughout the bud growth period. The results showed that when the data were adapted to the conditions of the Southern Hemisphere (Figure 2b), only the expression profile of VvPOD38 was 
consistent with the increase in POD activity during the development of ED, and VvPOD25 was expressed slightly during ED but increased before budbreak (Figure $2 b$ ).

\subsection{Expression Profile of RBOH throughout the Endodormancy Period in Grapevine Buds}

As one of the major sources of ROS in plants is the NADPH oxidase-catalysed conversion of oxygen to $\mathrm{O}_{2}{ }^{-}$, the expression of the $\mathrm{RBOH}$ genes in grapevine buds was analysed. Seven $V v R B O H$ genes have been identified in the V. vinifera genome [17], and three of them are expressed in the bud [18]. The transcript levels of $V v R B O H s$ taken from microarray data on the development of Tempranillo grape buds grown in the Northern Hemisphere [18] were plotted throughout the ED period. The results showed that when the data were adapted to the conditions of the Southern Hemisphere (Figure 3), the expression of $V v R-$ $B O H E$ was the only family member to have its transcriptional activity significantly altered during the development of $\mathrm{ED}$; however, its maximum expression level did not match the maximum level of $\mathrm{H}_{2} \mathrm{O}_{2}$.

\section{VvRBOHs}

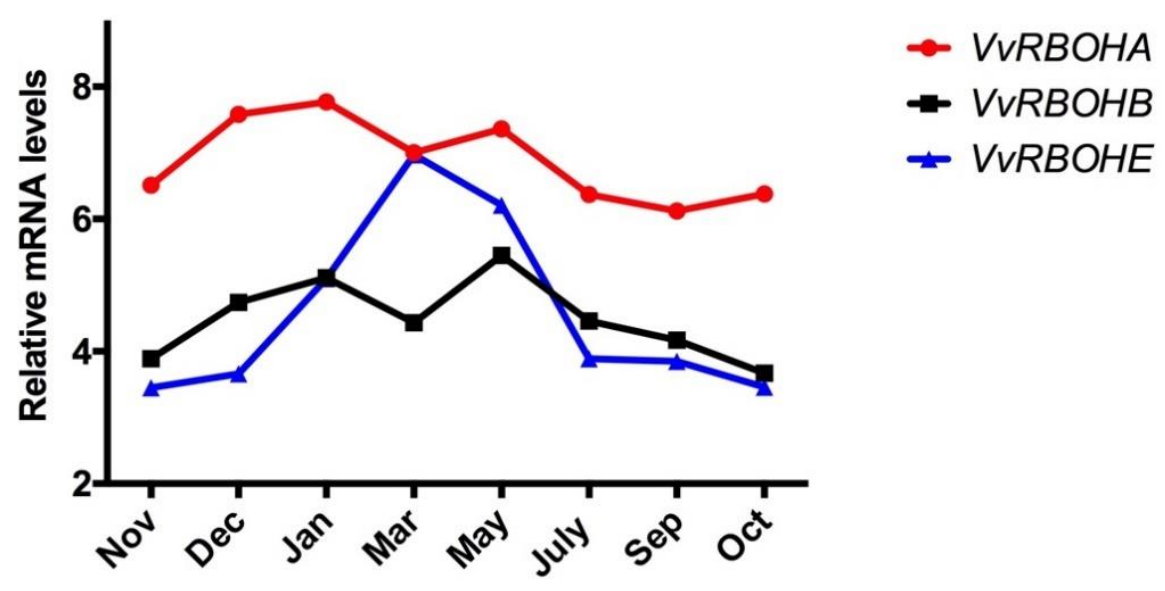

Figure 3. Expression profile of RESPIRATORY BURST OXIDASE HOMOLOGS (VvRBOHs) genes in grapevine buds during endodormancy. The expression profile of $V v R B O H$ genes in Tempranillo grapevine buds grown in Alcalá de Henares, Madrid [21] and adapted to the Southern Hemisphere conditions.

\subsection{Scavenging Activity of $\mathrm{H}_{2} \mathrm{O}_{2}$ during Endodormancy in Grapevine Buds}

It is well known that the ROS scavenging system is involved in the control of $\mathrm{H}_{2} \mathrm{O}_{2}$ in many plant developmental processes [33]. Here, we analysed the expression profile of the catalase genes $V v C A T 1$ and $V v C A T 2$ and catalase activity throughout the ED period in grapevine buds. The transcript levels of VvCAT1 and VvCAT2 taken from microarray data on the development of Tempranillo grape buds grown in the Northern Hemisphere [18] were plotted throughout the ED period. The results showed that when the data were adapted to the conditions of the Southern Hemisphere (Figure $4 \mathrm{~b}$ ), no major variations in the expression of $V v C A T 1$ and $V v C A T 2$ in the buds during their ED period were observed. Catalase activity also did not vary significantly during the ED period in Thompson seedless grapevines, but a peak was detected at the end of July (Figure 4a). As there is a correspondence between catalase activity and expression of catalase genes, the changes in activity reflect the changes in protein abundance. 
a VvCAT activity

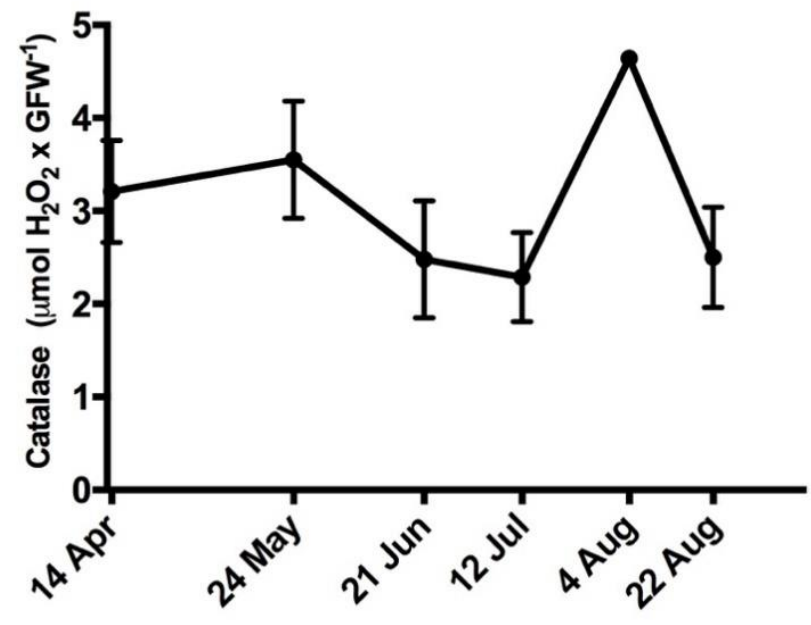

b

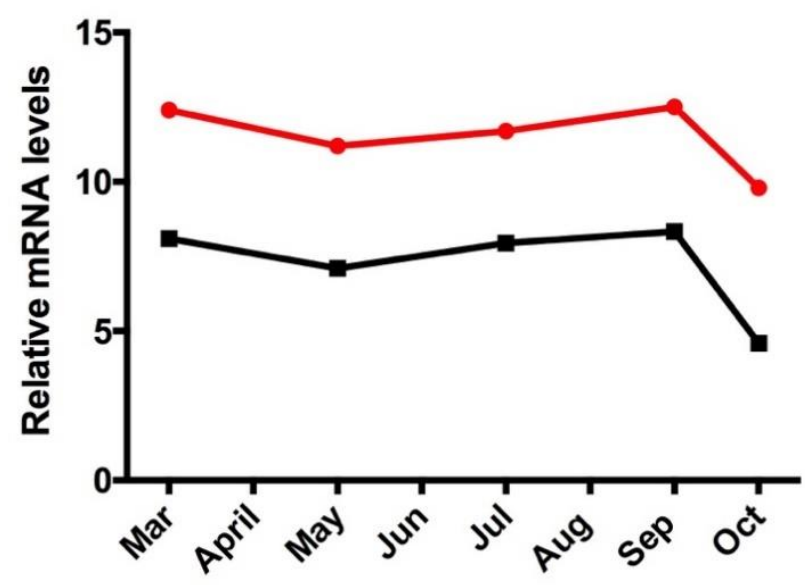

Figure 4. Catalase activity and expression of catalase genes in grapevine buds during endodormancy. (a) Catalase activity during endodormancy in Thompson seedless grapevine buds grown in Santiago, Chile. (b) Expression of catalase genes (VvCAT1 and VvCAT2) in buds of Tempranillo grapevines grown in Alcalá de Henares, Madrid [21] and adapted to the Southern Hemisphere conditions.

On the other hand, aminotriazole, an inhibitor of catalase activity [34], rapidly increased $\mathrm{H}_{2} \mathrm{O}_{2}$ content in grapevine buds collected at the end of the ED, and this high $\mathrm{H}_{2} \mathrm{O}_{2}$ level was maintained for longer than when buds were treated with $\mathrm{HC}$ (Figure $5 \mathrm{a}$ ). Furthermore, aminotriazole delayed the sprouting of grapevine buds relative to control buds (Figure $5 b$ ). 


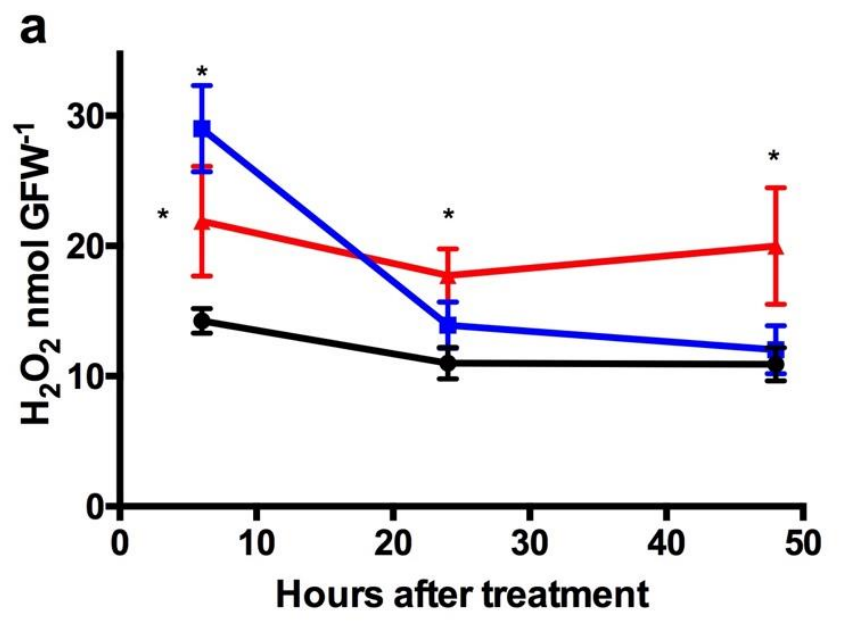

Control

$-\mathrm{HC}$

+ Aminotriazole

\section{b}

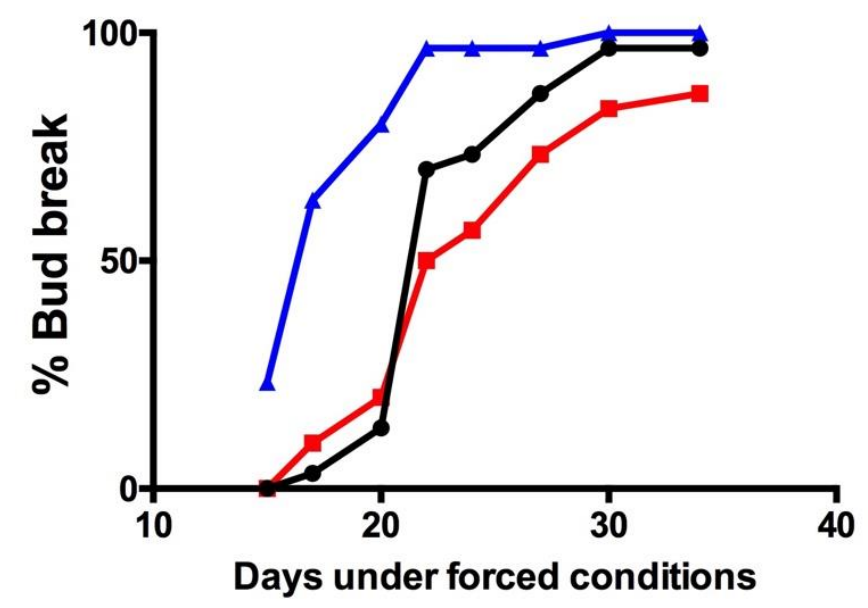

$\rightarrow$ Control

- Aminotriazole

$+\mathrm{HC}$

Figure 5. Aminotriazole effect on $\mathrm{H}_{2} \mathrm{O}_{2}$ content and budbreak in grapevine buds. The effect of aminotriazole (a) on the level of $\mathrm{H}_{2} \mathrm{O}_{2}$ and (b) on the budbreak of Thompson seedless grapevine buds was analysed. Buds collected at June 11 were excised into single-bud cuttings and sprayed with $2.5 \% \mathrm{HC}, 2 \%$ Aminotriazole and water as control. The treated single-bud cuttings were placed in the growth chamber and $\mathrm{H}_{2} \mathrm{O}_{2}$ was determined at the desired time by a chemiluminescence method [29]. Values are the average of three biological replicates $\pm \mathrm{SD}$; and $\left(^{*}\right)$ indicates statistically significance differences (Dunnett's multiple comparison test $\alpha=0.05$ ). Buds collected at July 18 were excised into single-bud cuttings (30 per treatment) and sprayed with $2.5 \% \mathrm{HC}, 2 \%$ Aminotriazole and water as control. The treated single-bud cuttings were placed in the growth chamber and budbreak was assessed by the presence of green tips.

\subsection{Variations in the $\mathrm{H}_{2} \mathrm{O}_{2}$ Content during Budbreak in Grapevine Buds under Forced Conditions}

To evaluate the changes in the $\mathrm{H}_{2} \mathrm{O}_{2}$ content during forcing budbreak, the $\mathrm{H}_{2} \mathrm{O}_{2}$ content was measured several days after the onset of the treatment in grapevine buds collected in early June, when they were endodormant [24] (Figure 6a). The $\mathrm{H}_{2} \mathrm{O}_{2}$ was also measured a few hours after the onset of the treatment in grapevine buds collected at the end of July, once the ED was finished and the buds were quiescent [24] (Figure 6b). The $\mathrm{H}_{2} \mathrm{O}_{2}$ content decreased rapidly in the quiescent buds (Figure 5b), while in the dormant buds the decrease in the $\mathrm{H}_{2} \mathrm{O}_{2}$ content was much slower (Figure 5a). 
a

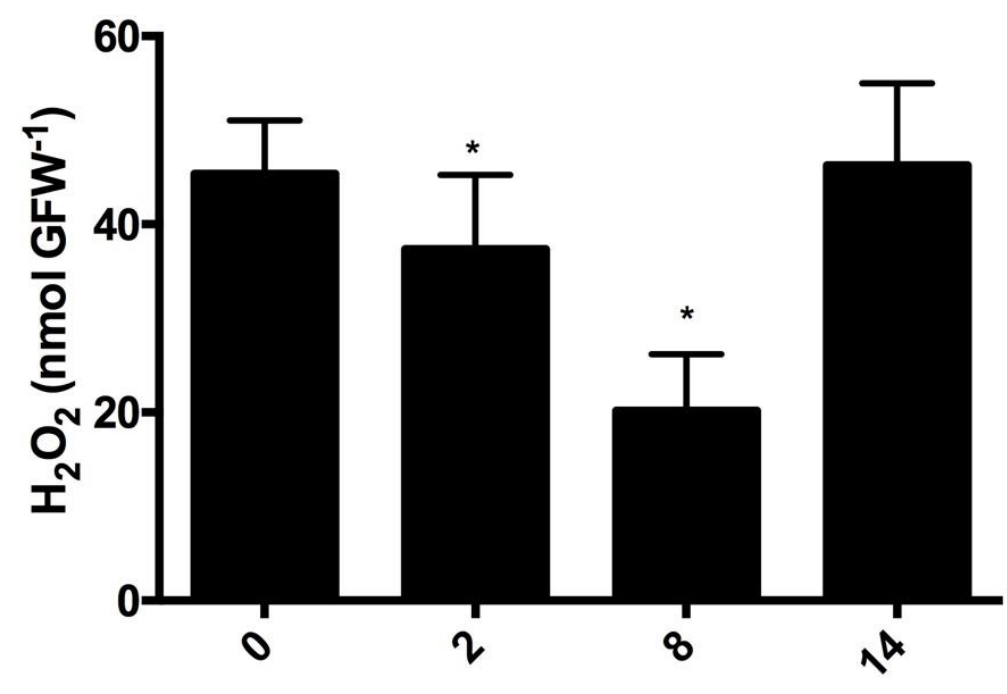

Days under forced conditions

b

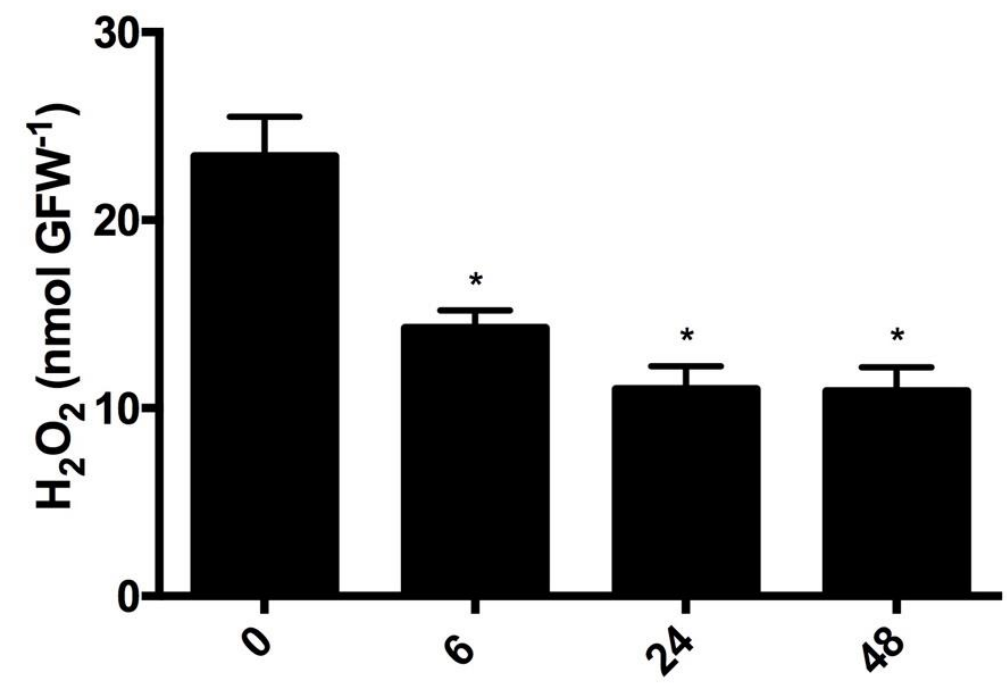

Hours under forced conditions

Figure 6. Rate of $\mathrm{H}_{2} \mathrm{O}_{2}$ reduction in dormant and quiescent grapevine buds under forcing budbreak. Decreases in $\mathrm{H}_{2} \mathrm{O}_{2}$ content in (a) endodormant and (b) quiescent buds of Thompson seedless grapevines under forced growth conditions. $\mathrm{H}_{2} \mathrm{O}_{2}$ was determined by a chemiluminescence method [29]. Values are the average of three biological replicates $\left.\pm \mathrm{SD} ;{ }^{*}\right)$ indicates statistically significance differences. Student's test $(\alpha=0.05)$.

3.7. Cytokinin-Inactivating Genes and Auxin Biosynthesis Genes Are Induced by $\mathrm{H}_{2} \mathrm{O}_{2}$ in Grapevine Buds, While Cytokinin Biosynthesis Genes Are Repressed

Cytokinin has an antagonistic function to auxin in different developmental processes [35]. Here, we analysed the effect of exogenous applications of $\mathrm{H}_{2} \mathrm{O}_{2}$ on the expression of the CK biosynthesis genes, VvIPT3a and VvLOG1, and the CK inactivating gene $V v C K X 3$ in grapevine buds. We selected these genes of $C K$ metabolism because 
their expression varied greatly during the sprouting of grapevine buds under forced conditions [36]. Additionally, the effect of $\mathrm{H}_{2} \mathrm{O}_{2}$ on the expression of the auxin biosynthesis genes, VvAMI1 and VvYUC3, and the auxin transport gene VvPIN3 was also analysed for the same reason mentioned above. The results showed that after $48 \mathrm{~h}$ of $\mathrm{H}_{2} \mathrm{O}_{2}$ treatment, the expression levels of the CK biosynthesis genes, VvIPT3a and VvLOG1 decreased, while that of the CK-inactivating gene $V v C K X 3$ increased (Figure 7a). These results suggest that $\mathrm{H}_{2} \mathrm{O}_{2}$ decreases the $\mathrm{CK}$ content in the grapevine buds. On the other hand, $\mathrm{H}_{2} \mathrm{O}_{2}$ increased the expression levels of the auxin biosynthesis genes VvAMI1 and VvYUC3 and of the auxin transport gene $V v P I N 3$ (Figure $7 \mathrm{~b}$ ) in grapevine buds. These results suggest that the auxin content and auxin transport are increased in grapevine buds after $\mathrm{H}_{2} \mathrm{O}_{2}$ treatment.

a
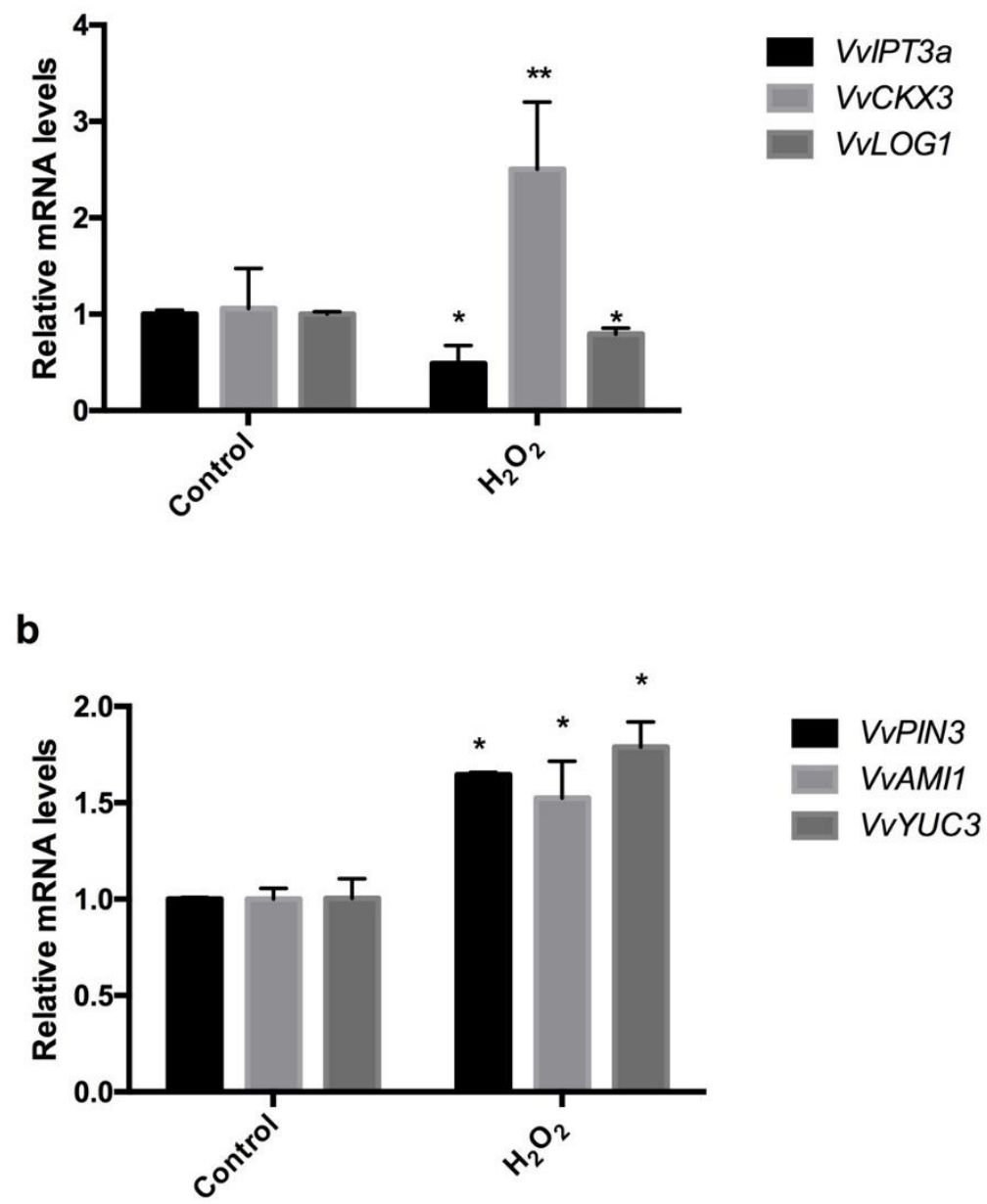

Figure 7. Transcriptional effect of $\mathrm{H}_{2} \mathrm{O}_{2}$ on the homeostasis of $\mathrm{CK}$ and auxin related genes. Effect of $\mathrm{H}_{2} \mathrm{O}_{2}$ applications on the expression of (a) cytokinin (CK) VvIPT3a, VvLOG1, and VvCKX3 and (b) auxin VvAMI1, VvYUC3 and VvPIN3 genes. Gene expression analysis was performed by RT-qPCR and normalised against VvUBIQITIN. Values are the average of three biological replicates with three technical repetitions $\pm \mathrm{SD} ;\left(^{*}\right)$ indicates statistically significance differences $p \leq 0.05 ;\left({ }^{* *}\right) p \leq 0.01$ (Dunnett's multiple comparison test).

\section{Discussion}

\section{1. $\mathrm{ABA}$ and $\mathrm{H}_{2} \mathrm{O}_{2}$ Accumulate in Grapevine Buds during ED}

Under stress conditions, abscisic acid (ABA) and hydrogen peroxide $\left(\mathrm{H}_{2} \mathrm{O}_{2}\right)$ accumulate in many plant biological systems [37,38]. In grapevine buds, both molecules accumulate during ED [5,6]. The ABA peak occurred before that of $\mathrm{H}_{2} \mathrm{O}_{2}[6]$ and the peak of $\mathrm{H}_{2} \mathrm{O}_{2}$ coincided with the maximum depth of the ED (Figure 1), which suggests 
that ABA could control the level of $\mathrm{H}_{2} \mathrm{O}_{2}$, which in turn, would be related to the depth of the ED in grapevine buds. In guard cells, $\mathrm{ABA}$ induces $\mathrm{H}_{2} \mathrm{O}_{2}$ production presumably via the activity of NADPH-oxidase [39]. In rice roots, $\mathrm{ABA}$ induces increases in $\mathrm{H}_{2} \mathrm{O}_{2}$ via activation of cell wall peroxidases [40]. In rice leaves under water stress, $\mathrm{ABA}$ controls $\mathrm{H}_{2} \mathrm{O}_{2}$ accumulation through the induction of the catalase gene OsCATB [41], and grafting-induced $A B A$ accumulation in cucumber leaves triggers $\mathrm{H}_{2} \mathrm{O}_{2}$ production and enhances the activities of antioxidant enzymes [42]. In grapevine, during bud $\mathrm{ED}, \mathrm{H}_{2} \mathrm{O}_{2}$ levels correlated with increases in POD activity and $V v P O D 38$ gene expression, but not with increases in $V v R B O H$ and $V v C A T$ gene expression, which suggested that during bud ED, the $\mathrm{H}_{2} \mathrm{O}_{2}$ content is controlled mainly by POD activity. Interestingly, ABA has been reported to regulate the expression of several $V v P O D$ genes in grapevine berry skins (Table S1) including $V v P O D 38[43,44]$, but its effect on $\mathrm{H}_{2} \mathrm{O}_{2}$ levels has not been described in grapevines. However, the role of $\mathrm{ABA}$ in bud ED and budbreak in grapevines has been extensively reported in the literature [7-9]. Thus, it has been shown that ABA represses the expression of cell cycle genes in the bud meristem of grapevine [8], and its removal is a key step for dormancy release $[7,9]$. Additionally, ABA promotes starch synthesis and storage metabolism in endodormant grapevine buds, thus contributing to the establishment of bud $\mathrm{ED}$ [6]. On the other hand, although $\mathrm{H}_{2} \mathrm{O}_{2}$ accumulates in grapevine buds during ED, its role in dormancy regulation has been associated mainly with the release of buds from ED rather than with their establishment and maintenance.

\subsection{The Role of $\mathrm{H}_{2} \mathrm{O}_{2}$ during Bud ED Release and Budbreak}

As the application of chemical and physical stimuli that break bud dormancy, such as hydrogen cyanamide (HC), sodium azide (AZ), heat shock (HS) and hypoxia, induces a transient increase in $\mathrm{H}_{2} \mathrm{O}_{2}$ levels $[15,45,46]$, the release of buds from ED has been associated with oxidative and respiratory stress [14]. Recently, it has been demonstrated that HC transiently increases $\mathrm{H}_{2} \mathrm{O}_{2}$ levels and the expression of the VvPOD72 (GSVIVT01029771001) gene in paradormant grapevine buds [45], and in a proteomic study, it was demonstrated that $\mathrm{HC}$ induces the expression of $V v P O D 25$ [19], a gene that is weakly expressed during $\mathrm{ED}$ and more highly expressed during budbreak. All these studies suggest that the transient increase in $\mathrm{H}_{2} \mathrm{O}_{2}$ levels observed in grapevine buds after being treated with $\mathrm{HC}$ is due either to an increase in the expression of $V v P O D$ genes or to the inhibition of catalase activity $[12,13]$. The transient increase in $\mathrm{H}_{2} \mathrm{O}_{2}$ levels could act as a secondary messenger, triggering the expression of genes related to endodormancy release [13]. However, when $\mathrm{H}_{2} \mathrm{O}_{2}$ levels remained high for a long period of time, such as after aminotriazole treatment, the budbreak was delayed (Figure 7). In rose flower buds, the content of $\mathrm{H}_{2} \mathrm{O}_{2}$ decreases during the outgrowth process as a result of the activation of the ascorbic acid-glutathione (ASA-GSH) cycle [47]. Additionally, exogenous applications of $\mathrm{H}_{2} \mathrm{O}_{2}$ to rose buds delay their outgrowth and inhibit the expression of key genes involved in bud outgrowth, such as VACUOLAR INVERTASE (RhVI), EXPANSIN (RhEXP), PROLIFERATING CELL NUCLEAR ANTIGEN (RhPCNA) and CYCLIN D3 (RHCYCD3) [47]. These results indicate that $\mathrm{H}_{2} \mathrm{O}_{2}$ negatively controls the outgrowth of rose buds. Our results on the budbreak of quiescent grapevine buds under forced conditions showed a rapid drop in the $\mathrm{H}_{2} \mathrm{O}_{2}$ content with budbreak progress, while in dormant buds, this drop was slower, indicating that $\mathrm{H}_{2} \mathrm{O}_{2}$ should be removed from the bud by the antioxidative system before budbreak and the resumption of growth begins. In addition, the fact that exogenous applications of $\mathrm{H}_{2} \mathrm{O}_{2}$ reduce the $\mathrm{CK}$ content by inducing the expression of the $\mathrm{CK}$ degrading gene $(\mathrm{Vv} C \mathrm{CX} 3)$ and repressing the expression of the CK biosynthesis genes (VvIPT3a and VvLOG1) suggests that $\mathrm{H}_{2} \mathrm{O}_{2}$ negatively affects budbreak, since $\mathrm{CK}$ positively modulates cell division and proliferation in meristematic tissue [48]. One of the first cellular events that occurs before the onset of budbreak in grapevine buds is the increase in the expression of CK biosynthesis genes as well as for genes related to the cell cycle $[49,50]$. In tomato plants, $\mathrm{H}_{2} \mathrm{O}_{2}$ promotes auxin biosynthesis in the apex, which, in turn, inhibits CK biosynthesis and subsequent bud outgrowth [51]. This result agrees with our results obtained in the grapevine buds 
which indicates an increase in the expression of auxin biosynthesis and transport genes after $\mathrm{H}_{2} \mathrm{O}_{2}$ treatments (Figure $6 \mathrm{~b}$ ).

\section{Conclusions}

During the development of ED in grapevine buds, the level of $\mathrm{H}_{2} \mathrm{O}_{2}$ increased as a result of a higher expression of the $\mathrm{VvPODs}$ genes, whose transcription could be regulated by ABA. On the contrary, during budbreak, the $\mathrm{H}_{2} \mathrm{O}_{2}$ level decreased. This difference, in changes in the level of $\mathrm{H}_{2} \mathrm{O}_{2}$ during bud development, is consistent with the transcriptional effect of $\mathrm{H}_{2} \mathrm{O}_{2}$ on the genes that regulate $\mathrm{CK}$ and auxin metabolism.

Supplementary Materials: The following are available online at https: / www.mdpi.com/article/ 10.3390 /antiox10060873/s1, Table S1: V. vinifera peroxidase genes (VvPODs) whose expression is regulated by $\mathrm{ABA}$.

Author Contributions: Conceptualization F.J.P.; Methodology X.N., S.R., F.J.P.; Software S.R., X.N., F.J.P., Formal analysis, X.N., S.R., F.J.P.; Investigation X.N., S.R., F.J.P.; Resources F.J.P.; Writing F.J.P., Administration F.J.P.; Funding acquisition F.J.P. All authors have read and agreed to the published version of the manuscript.

Funding: This research was funding by Fondecyt project \#1190057.

Institutional Review Board Statement: Not applicable.

Informed Consent Statement: Not applicable.

Data Availability Statement: Data is contained within the article.

Conflicts of Interest: The authors declare no conflict of interest.

\section{References}

1. Kühn, N.; Ormeño-Nuñez, J.; Jaque-Zamora, G.; Pérez, F.J. Photoperiod modifies the diurnal expression profile of VvPHYA and VvPHYB transcripts in field-grown grapevine leaves. J. Plant Physiol. 2009, 66, 1172-1180. [CrossRef]

2. Grant, T.N.L.; Gargrave, J.; Dami, I.E. Morphological physiological, and biochemical changes in Vitis genotype in responses to photoperiod regimes. Am. J. Enol. Vitic. 2013, 64, 466-475. [CrossRef]

3. Cragin, J.; Serpe, M.; Keller, M.; Shellie, K. Dormancy and cold hardiness transition in wine grape cultivars Chardonnay and Cabernet Sauvignon. Am. J. Enol. Vitic. 2017, 68, 195-202. [CrossRef]

4. Lang, G.A. Dormancy: A new universal terminology. HortScience 1987, 22, 817-820.

5. Or, E.; Belausov, E.; Popilevski, I.; Tal, Y.B. Changes in endogenous ABA level in relation to the dormancy cycle in grapevines grown in a hot climate. J. Hortic. Sci. Biotechnol. 2000, 75, 190-194. [CrossRef]

6. Rubio, S.; Noriega, X.; Pérez, F.J. ABA promotes starch synthesis and storage metabolism in dormant grapevine buds. J. Plant Physiol. 2019, 234, 1-8. [CrossRef] [PubMed]

7. Zheng, C.H.; Halaly, T.; Acheampong, A.K.; Takebayashi, Y.; Jikumaru, Y.; Kamiya, Y.; Or, E. Abscisic acid (ABA) regulates grape bud dormancy, and dormancy release stimuli may act through modification of ABA metabolism. J. Exp. Bot. 2015, 66, 1527-1542. [CrossRef] [PubMed]

8. Vergara, R.; Noriega, X.; Pérez, F.J. ABA represses the expression of cell cycle genes an may modulate the development of endodormancy in grapevine buds. Front. Plant Sci. 2017, 8, 812. [CrossRef]

9. Zheng, C.; Acheampog, A.K.; Shi, Z.; Mugzech, A.; Halaly-Basha, T.; Shaya, F.; Sun, Y.; Colova, V.; Mosquna, A.; Ophir, R.; et al. Abscisic acid catabolism enhances dormancy release of grapevine buds. Plant Cell Environ. 2018, 1, 14. [CrossRef]

10. Neil, S.; Desikan, R.; Hancock, J. Hydrogen Peroxide signaling. Curr. Opin. Plant Biol. 2002, 5, 388-395. [CrossRef]

11. Pérez, F.J.; Burgos, B. Alterations in the pattern of peroxidase isoenzymes and transient increases in its activity and in $\mathrm{H}_{2} \mathrm{O}_{2}$ levels take place during the dormancy cycle of grapevine buds: The effect of hydrogen cyanamide. Plant Growth Regul. 2004, 43, 213-220. [CrossRef]

12. Pérez, F.J.; Lira, W. Possible role of catalase in post-dormancy bud break in grapevines. J. Plant Physiol. 2005, 162, 301-308. [CrossRef] [PubMed]

13. Pérez, F.J.; Vergara, R.; Rubio, $\mathrm{S} . \mathrm{H}_{2} \mathrm{O}_{2}$ is involved in the dormancy-breaking effect of hydrogen cyanamide in grapevine buds. Plant Growth Regul. 2008, 55, 149-515. [CrossRef]

14. Beauvieux, R.; Wenden, B.; Dirlewanger, E. Bud dormancy in perennial fruit tree species: A pivotal role for oxidative cues. Front. Plant Sci. 2018, 9, 657. [CrossRef]

15. Vergara, R.; Parada, F.; Rubio, S.; Pérez, F.J. Hypoxia induces $\mathrm{H}_{2} \mathrm{O}_{2}$ production and activates antioxidant defense system in grapevine buds through mediation of $\mathrm{H}_{2} \mathrm{O}_{2}$ and ethylene. J. Exp. Bot. 2012, 63, 4123-4131. [CrossRef] 
16. Baxler-Burrel, A.; Yang, Z.; Springer, P.S.; Bailey-Seres, J. RopGAP4-dependent Rop-GTPase rheostat control of Arabidopsis oxygen de privation tolerance. Science 2002, 296, 2026-2028. [CrossRef]

17. Cheng, C.; Xu, X.; Gao, M.; Li, J.; Guo, C.; Song, J.; Wang, X. Genome-Wide analysis of respiratory burst oxidase homologs in grape (Vitis vinifera L.). Int. J. Mol. Sci. 2013, 14, 24169-24186. [CrossRef] [PubMed]

18. Díaz-Riquelme, J.; Grimplet, J.; Martínez-Zapater, J.M.; Carmona, M.J. Transcriptome variation along bud development in grapevine. BMC Plant Biol. 2012, 12, 181. [CrossRef]

19. Khalil-Ur-Rehman, M.; Wang, W.; Dong, Y.; Faheem, M.; Xu, Y.; Gao, Z.; Tao, J. Comparative transcriptomic and proteomic analysis to deeply investigate the role of hydrogen cyanamide in grape bud dormancy. Int. J. Mol. Sci. 2019, 20, 3528. [CrossRef]

20. Xiao, H.; Wang, C.; Khan, N.; Chen, M.; Fu, W.; Guan, L.; Leng, X. Genome-wide identification of class III POD gene family and their expression profiling in grapevine (Vitis vinifera L.). BMC Genom. 2020, 21, 444. [CrossRef]

21. Koussa, T.; Broquedis, M.; Bouard, J. Changes of abscisic acid during the development of latent buds particularly in the phase of dormancy break. Vitis 1994, 33, 63-67.

22. Dennis, G. Problems in standardizing methods for evaluating the chilling requirements for the breaking of dormancy in buds of woody plants. HortScience 2003, 38, 347-350. [CrossRef]

23. Camargo Alvarez, H.; Salazar-Gutierrez, M.; Zapata, D.; Keller, M.; Hoogenboom, G. Time to event analysis to evaluate dormancy status of single-bud cuttings: An example for grapevines. Plant Methods 2018, 14, 94. [CrossRef]

24. Vergara, R.; Pérez, F.J. Similarities between natural and chemically induced bud-endodormancy release in grapevine Vitis vinifera L. Sci. Hortic. 2010, 125, 648-653. [CrossRef]

25. Rubio, S.; Dantas, D.; Bressan-Smith, R.; Pérez, F.J. Relationship between endodormancy and cold hardiness in grapevine buds. J. Plant Growth Regul. 2016, 35, 266-275. [CrossRef]

26. Pérez, F.J.; Rubio, S. An improved chemiluminescence method for hydrogen peroxide determinations in plant tissues. Plant Growth Regul. 2006, 48, 89-95. [CrossRef]

27. Pérez, F.J.; Gómez, M. Gibberelic acid stimulation of isoperoxidase from pedicel of grape. Phytochemistry 1998, 48, 411-414. [CrossRef]

28. Chang, S.; Puryear, J.; Cairney, J. A simple and efficient method for isolating RNA from pine trees. Plant Mol. Biol. Rep. 1993, 11, 113-116. [CrossRef]

29. Noriega, X.; Burgos, B.; Pérez, F.J. Short-day photoperiod triggers and low temperatures increase expression of peroxidase RNA transcripts and basic peroxidase isoenzyme activity in grapevine-buds. Phytochemitry 2007, 68, 1376-1383. [CrossRef] [PubMed]

30. Rozen, S.; Skaletsky, H. Primer3 on the www for general users and for biologist programmers. Methods Mol. Biol. 2000, 132, 365-386.

31. Livak, K.J.; Schmittgen, T.D. Analysis of relative gene expression data using real-time quantitative PCR and the 2- $\Delta \Delta C T$ method. Methods 2001, 25, 402-408. [CrossRef] [PubMed]

32. Altman, D.G.; Bland, J.M. Time to event survival data. BMJ 1998, 317, 468-469. [CrossRef] [PubMed]

33. Das, K.; Roychoudhury, A. Reactive oxygen species (ROS) and response of antioxidants as ROS-scavengers during environmental stress in plants. Front. Environ. Sci. 2014, 2, 1-13. [CrossRef]

34. Nicholls, P. The reaction between aminotriazole and catalase. Biochem. Biophys. Acta 1962, 59, 414-420. [CrossRef]

35. Moubayidin, L.; Di Mambro, R.; Sabatini, S. Cytokinin-auxin crosstalk. Trends Plant Sci. 2009, 14, 557-562. [CrossRef]

36. Noriega, X.; Pérez, F.J. ABA biosynthesis genes are down-regulated while auxin and cytokinin biosynthesis gene are up-regulated during the release of grapevine from endodormancy. J. Plant Growth Regul. 2017, 36, 814-823. [CrossRef]

37. Assmann, S.M.; Shimazaki, K.I. The multisensory guard cell, stomatal responses to blue light and abscisic acid. Plant Physiol. 1999, 119, 809-815. [CrossRef]

38. Potikha, T.S.; Collins, C.C.; Johnson, D.I.; Delmer, D.P.; Levine, A. The involvement of hydrogen peroxide in the differentiation of secondary walls in cotton fibers. Plant Physiol. 1999, 119, 849-858. [CrossRef]

39. Zhang, X.; Zhang, L.; Dong, F.; Gao, J.; Galbraith, W.; Song, C. Hydrogen Peroxide is involved in abscisic acid-induced stomatal closure in Vicia faba. Plant Physiol. 2001, 126, 1428-1448. [CrossRef]

40. Lin, C.C.; Kao, C.H. Abscisic acid induced changes in cell wall peroxidase activity and hydrogen peroxide level in roots of rice seedlings. Plant Sci. 2001, 160, 323-329. [CrossRef]

41. Ye, N.; Zhu, G.; Liu, Y.; Li, Y.; Zhang, J. ABA controls $\mathrm{H}_{2} \mathrm{O}_{2}$ accumulation through the induction of OsCATB in rice leaves under water stress. Plant Cell Physiol. 2011, 54, 689-698. [CrossRef]

42. Shu, S.; Gao, P.; Li, L.; Yuan, Y.; Sun, J.; Guo, S. Abscicic acid-induced $\mathrm{H}_{2} \mathrm{O}_{2}$ accumulation enhances antioxidant capacity in pumpkin-grafted cucumber leaves under $\mathrm{Ca}\left(\mathrm{NO}_{3}\right)_{2}$ stress. Front. Plant Sci. 2016, 7, 1489. [CrossRef]

43. Pilati, S.; Bagagli, G.; Sonego, P.; Moretto, M.; Brazzale, D.; Castorina, G.; Simoni, L.; Tonelli, C.; Guella, G.; Engelen, K.; et al. Abscisic acid is a major regulator of grape berry ripening onset. New insights into ABA signaling network. Front. Plant Sci. 2017, 8, 1093. [CrossRef]

44. Nicolas, P.; Lecourieux, D.; Kappel, C.; Cluzet, S.; Cramer, G.; Delrot, S.; Lecorieux, F. The basic Leucine-Zipper transcription factor ABSICISIC ACID RESPONSE ELEMENT-BINDING FACTOR2 is an important transcriptional regulator of absicisic-dependent grape berry ripening processes. Plant Physiol. 2014, 164, 365-383. [CrossRef] 
45. Sudawan, B.; Chang, C.; Chao, H.; Ku, M.S.; Yen, Y. Hydrogen cyanamide breaks grapevine buds dormancy in the summer through transient activation of gene expression and accumulatio of reactive oxygen and nitrogen species. BMC Plant Biol. 2016, 16, 202. [CrossRef]

46. Mohamed, H.; Zrig, A.; Geuns, J.M.C.; Khemira, H. Near-lethal heat treatment induced metabolic changes associated with endodormancy release of Superior Seedless grapevine cv. (Vitis vinifera L.) buds. Aust. J. Crop. Sci. 2014, 8, 486-494.

47. Porcher, A.; Guérin, V.; Montrichard, F.; Lebrec, A.; Lothier, J.; Vian, A. Ascorbate glutathione-dependent $\mathrm{H}_{2} \mathrm{O}_{2} \mathrm{scavenging}$ is an important process in axillary bud outgrowth in rosebush. Ann. Bot. 2020, 126, 1049-1062. [CrossRef]

48. Azizi, P.; Rafi, M.Y.; Maziah, M.; Abdullah, S.N.A.; Hanafi, M.M.; Latif, M.A.; Rashid, A.A.; Sahebi, M. Understanding the shoot apical meristem regulation: Astudy of the phytohormones, auxin and cytokinin, in rice. Mech. Dev. 2015, 135, 1-15. [CrossRef]

49. Noriega, X.; Pérez, F.J. Cell cycle genes are activated earlier than respiratory genes during release of grapevine buds from endodormancy. Plant Signal. Behav. 2017, 12, e1321189. [CrossRef]

50. Pérez, F.J.; Noriega, X. Sprouting of paradormant and end dormant grapevine buds under conditions of forced growth: Similarities and differences. Planta 2018, 248, 837-847. [CrossRef] [PubMed]

51. Chen, X.J.; Xia, X.J.; Guo, X.; Zhou, Y.H.; Shi, K.; Zhou, J.; Yu, J.Q. Apoplastic $\mathrm{H}_{2} \mathrm{O}_{2}$ plays a critical role in axillary bud outgrowth by altering auxin and cytokinin homeostasis in tomato plants. New Phytol. 2016, 211, 1266-1278. [CrossRef] [PubMed] 